Breast cancer is the most common type of malignant neoplasm affecting women. In Poland there are nearly 15500 new cases of the disease and over 5200 deaths due to it observed annually. As it was necessary to provide those suffering from breast cancer with combined highly specialist treatment, it was required that separate units specialising in breast surgery be established. In Europe they are referred to as Breast Units. The idea of forming such separate and fully profiled centres specialising in breast diseases, which was developed in 1998 by EORTC, EUSOMA as well as Europa Donna, gave foundations for the organisation of such centres. The situation of Breast Units in other European countries is different. Poland has failed so far to organise an effective system of Breast Units. Leading Polish authorities underline that formation of multi-disciplinary Breast Units is the organisational priority for the year 2013.

Key words: Breast Units, Poland, modern surgical techniques.

Contemp Oncol (Pozn) 2014; 18 (4): 227-229 DOI: $10.5114 /$ wo.2014.43489

\section{Standards in breast surgery - Breast Units - future and necessity}

\section{Barbara Teresa Madej-Czerwonka}

Department of Breast Surgery, Specialist County Hospital of Stephan Cardinal Wyszyński in Lublin, Medical University of Lublin, Poland

Breast cancer is the most common type of malignant neoplasm affecting women. In Poland there are nearly 15500 new cases of the disease and over 5200 deaths due to it observed annually [1]. It accounts for $22.4 \%$ of all neoplasms in women and it is the result of $12.9 \%$ of deaths due to malignant neoplasms. Every year worldwide there are approximately 1.4 million new cases of breast cancer diagnosed and 450000 deaths. Breast cancer is also the most common reason for morbidity from neoplastic diseases - patients affected with this type of neoplasm account for $1 / 3$ of women diagnosed with a malignant neoplasm. Under $1 \%$ of cases are men diagnosed with breast cancer [2]. Effective treatment of the disease is the main priority in most European countries including Poland.

Research conducted recently on etiology and development of breast cancer has changed opinions held to date concerning recommended methods of treatment of the disease. The disease has started to be perceived not only as locoregional but systemic and consequently it has been reflected in modifications of surgical methods and changes in chemotherapy schemes. The use of low-invasive techniques in breast surgery such as sentinel lymph node biopsy or oncoplastic techniques used as standard procedures has met patients' aesthetic expectations [3]. The development of molecular biology has enabled the use of guided therapies. However, formation of distant metastases, which is the major factor undermining effective treatment of the disease, still remains unsolved.

As it was necessary to provide those suffering from breast cancer with combined highly specialist treatment as well as more complex early diagnostics, it was required that separate units specialising in breast surgery be established. In Europe they are referred to as Breast Units. The organisation of such institutions has become an objective of most European countries including Poland. The idea of forming such separate and fully profiled centres specialising in breast disease diagnostics and treatment, which was developed in Florence in 1998 by the European Organization for the Research and Treatment of Cancer Breast Cancer Cooperative Group (EORTC-BCCG), the European Society of Mastology (EUSOMA) as well as Europa Donna [4-6], gave foundations for the organisation of such centres. According to decisions made in Florence, there should be one Breast Unit for approximately 250000 inhabitants. It was underlined that such units have to be equipped with highly specialised experts in the field of clinical oncology, oncological surgery, cosmetic and reconstructive surgery, radiology, radiotherapy, psychotherapy, pathomorphology and nursing care. It was highlighted that screening centres should be part of Breast Units and radiologists evaluating screening mammography images should be included in the personnel of Breast Unit Department.

In addition to that, a Breast Unit should have at least two surgeons specialising in breast surgery who operate on at least 50 diagnosed cases of breast cancer annually and are able to perform basic reconstructive procedures as well as use oncoplastic surgery techniques. A Breast Unit should be capable of performing sentinel lymph node procedures. Such a centre should 
also be able to consult a plastic surgeon specialising in breast reconstruction. A Breast Unit should diagnose and treat patients having benign breast diseases.

Poland has failed so far to organise an effective system of Breast Units. Nevertheless, it has been planned to establish 20 such units by 2016. Nowadays the majority of departments treating breast neoplasms are departments of either general surgery or oncological surgery. Doctors employed in such departments have little experience in diagnostics and modern breast surgery techniques, are not trained in performing cosmetic or reconstructive surgery and therefore they do not perform breast conservation operations, sentinel lymph node biopsy or breast reconstruction. The equipment available in such units does not comply with the standards of state-of-the-art departments of breast surgery. The treatment of patients diagnosed with colon cancer and breast cancer in the same department makes it impossible to maintain appropriate conditions to implant prostheses or perform complicated reconstructive procedures. There are several departments in Poland which specialise in diagnosis and treatment of only breast diseases but only a few of them are certified.

The need of organisational changes and application of modern oncoplastic techniques has been discussed repeatedly during congresses of the Polish Associations of Surgical and Oncological Surgery. The pioneer in introduction of the above-mentioned improvements was Prof. Janusz Jaśkiewicz from the Medical University of Gdansk $[2,7]$. Following European organisational trends Prof. Krzysztof Herman - National Consultant for Oncological Surgery - has published organisational recommendations for Breast Units [8]. Surgical treatment of breast cancer in Poland should be provided in specialised units called Breast Cancer Units. Such units should meet the following requirements: the possibility to organise multidisciplinary consultation on site (oncological surgeon, clinical oncologist, radiotherapist, pathologist, radiologist), availability of a fully equipped operating theatre with intensive care unit on site, possibility of performing intraoperational histopathological examination on site, possibility of performing intraoperational mammography on site and intraoperational scintigraphy in order to determine the sentinel lymph node, ability to provide possible complementary treatment (chemotherapy, radiotherapy) on site or on the basis of an agreement with a different clinical centre. It should employ at least two oncological surgeons specialising in breast cancer surgery and treat annually at least 150 patients suffering from breast diseases. A necessary condition for a Breast Unit is its cooperation with a unit conducting breast cancer screening examinations and a genetic research laboratory. It is also necessary for it to carry out an analysis of early and distant therapeutic results and to conduct research and didactic activity.

Opinions about establishing Breast Units held among leading Polish authorities in the field of oncology are divided. As underlined by Prof. Bogusław Maciejewski from the Oncology Institute in Gliwice, Poland has too few specialists in order to be able to found new units. The author thinks that a more effective move would be to form units specialising in treating breast cancer on the basis of al- ready existing hospital departments which are able to provide multiprofile teams of specialists. Professor Maciejewski is of the opinion that in Poland there have been Breast Units for years although they have not been referred to as such or they have not been awarded an official certificate. He also asks the question who should be responsible for certifying such units [9].

According to the National Consultant for Oncological Surgery, we should do our best to establish such units. They function well in other countries, having a significant influence on the decrease of morbidity rate among women due to breast cancer [8-10]. As highlighted by Prof. Krzysztof Herman, in Poland there are only 26 fully profiled units specialising in treating breast neoplasms. A special team of experts in the field of oncology is working on the improvement of the situation concerning oncology in Poland. It has been established by the Senate Commission for Health in order to introduce necessary organisational changes. Professor Jacek Jassem underlines that formation of multi-disciplinary Breast Units, development of a modern system of molecular diagnostics of neoplasms and introduction of a unified protocol of pathomorphological examinations are the organisational priorities for the year 2013 [11].

The situation of Breast Units in other European countries is different. Taran and Eggemann [12] published an analysis concerning the functioning of Breast Units in 9 European countries 9 years after European Society of Breast Cancer Specialists (EUSOMA) issued its guidelines and 6 years after the European Parliament compiled a report on breast cancer [12-14]. The analysis was based on a questionnaire consisting of 5 questions concerning certification (whether it is conducted, and if so then who does it, whether governmental units are responsible for that or rather private organisations), the number of Breast Units in each country, the number of such units to be established and the frequency of inspections performed. The data have been obtained from national scientific societies, organisations specialising in breast cancer and experts in the field of breast cancer treatment. The following countries from the European Union were subject to analysis: Austria, the United Kingdom, Ireland, Iceland, Holland, Sweden, Spain, Norway and Germany [12].

The data collected were quite surprising. In 7 out of all analysed countries departments in which breast diseases are treated were awarded a certificate. However, in Sweden and in Norway Breast Units are not subject to certification. Certification is conducted by private units in Austria, Spain and Germany. Moreover, public certification is performed in departments from 4 countries: the UK, Ireland, Iceland and Holland. The frequency of conducting inspections in Breast Units differs depending on the country. Annual inspections are carried out in Germany, Austria and in Ireland. Units in the UK are inspected every 3 years and in the majority of other countries no inspections are conducted.

The number of established Breast Units is as follows: Iceland - 1, Sweden - 5, Austria, Ireland and Holland have 8 breast units each, Norway - 19, Spain - 80, Germany 182, UK -500 . In the future, the highest number of Breast 
Units to be formed is planned in Austria - 30, Norway - 19, Ireland -8 and Sweden -5 [12].

The European School of Oncology created an Internet network dedicated to units specialising in breast cancer treatment. The Breast Centres Network is the first international network of clinical centres exclusively dedicated to the diagnosis and treatment of breast cancer. This network provides information about the number of breast units in different European countries. The data concerns 16 countries in which there have been about 77 units registered since 2009, whereas 21 of them were certified by EUSOMA [12]. The highest number of Breast Units was found in Germany (21) and in Belgium (17). However, there are also single Breast Unit centres in the Czech Republic, Bulgaria and Turkey. France has an effective system of such units.

It is worth analysing how certain organisational ideas influence the rate of detectability of breast cancer and morbidity due to it in given European countries. On the basis of the EUROCARE-4 study published in 2007 it was shown that the chances for survival of women suffering from breast cancer vary depending on geographical area in Europe [15]. The greatest incidence of the disease is observed in northern Europe, though those countries as well as central European countries are characterised by the highest survival rate (except for Denmark). Southern European countries have moderate rates of incidence of the disease and morbidity except for the UK and Ireland. The lowest incidence of the disease and the highest morbidity are observed in eastern European countries including Poland [5].

The UK provides an interesting example. On the basis of the data collected from national oncological organisations it is known that the UK has almost 500 hospitals organised in a network which specialise in the treatment of that neoplasm and breast cancer therapy is supervised by a main consultant in that field. Such an organisational solution is different from those described and functioning in other countries. The UK has the highest number of units treating breast cancer of all analysed countries. The analysis shows a noticeable disproportion between a huge number of units specialising in the treatment of breast diseases and a low survival rate which is significantly higher in the countries characterised by similar economic development and having fewer Breast Units. Units in the UK are inspected the least frequently and they have national certification [12].

Commenting on Polish attempts to establish a system of Breast Units, it is worth underlining that one of the EUSOMA guidelines was to organise units specialising in breast cancer treatment as well as treatment of benign lesions within breasts. However, the introduction of the name Breast Cancer Units in Poland suggests that these centres will treat patients suffering from breast cancer exclusively. In my opinion, creating a separate field of interests for patients with benign diseases poses a potential risk of a less precise diagnosis and consequently it may have an influence on the worsening of all results of treatment. It seems that centres specialising in breast diseases should be called Breast Units or in Polish Oddziaty Chorób Piersi or Oddziaty Chirurgii Piersi (that is Departments of
Breast Diseases or Departments of Breast Surgery). All experts specialising in breast cancer treatment in Poland are impatiently waiting for such units to be established.

The author declares no conflict of interest.

\section{References}

1. Wojciechowska U, Didkowska J. Nowotwory w Polsce w 2012 roku. Nowotwory. J Oncol 2013; 63: 197-216.

2. Krzakowski M, Herman K, Jassem J. Zalecenia postępowania diagnostyczno-terapeutycznego w nowotworach złośliwych. Via Medica, Gdańsk 2007.

3. Tabar L. Breast Cancer. Medipage, Warszawa 2010.

4. Cataliotti L, Costa A, Daly PA, et al. Florence Statement on breast cancer, 1998. Forging the way ahead for more research on and better care in breast cancer. Eur J Cancer 1999; 35: 14-16.

5. Cataliotti L, De Wolf C, Holland R, et al. Guidelines on the standards for the training of specialised health professionals dealing with breast cancer. Eur J Cancer 2007; 43: 660-675.

6. Silverstein MJ. State-of-the-art breast units - a possibility or a fantasy? A comment from the US. Eur J Cancer 2000; 36: 2283-2285.

7. Jaśkiewicz J, Rak P, Chruścicka I, et al. Zastosowanie metody „CYTORI" w chirurgii rekonstrukcyjnej i estetycznej: doświadczenia własne. Nowotwory. J Oncol 2011; 61 Supl. 3: 16-17.

8. Bębenek M, Cichocki A, Grodecka-Gazdecka S, et al. Rekomendacje organizacyjne. Polskie Towarzystwo Chirurgii Onkologicznej: konsultant@chirurgiaonkologiczna.org.pl

9. Pustułka A. Prof. Maciejewski: Każdy rak jest inny. Gdzie powstaną breast units? Dziennik Zachodni 23.10.2012: http://www. dziennikzachodni.pl/artykul/682867, prof-maciejewski-kazdyrak-jest-inny-gdzie-powstana-breast,id,t.html.

10. Pustułka A. Breast Unit są niezbędne. 17.10.2012, gazeta.pl: http:// pulsmedycyny.pl/2702367,64090, breast-unit-sa-niezbedne.

11. Wysocka M. Onkolog z poczuciem misji - prof. Jacek Jassem. Puls Medycyny 27.02.2013: http://pulsmedycyny.pl/3018391,18393,3.onkolog-z-poczuciem-misji-prof.-jacek-jassem.

12. Taran FA, Eggemann H. Breast Units in Europe - Certification in 9 European Countries 9 Years after the European Society of Mastology Position Paper. Breast Care (Basel) 2009; 4: 219-222.

13. Bericht über Brustkrebs in der Europäischen Union (2002/2279 (INI)). Ausschuss für die Rechte der Frau und Chancengleichheit. Berichterstatterin: Karin Jöns. Europäisches Parlament 2003; 7.

14. EUSOMA. The requirements of a specialist breast unit. Position paper. Eur J Cancer 2000; 36: 2288-93.

15. Berrino F, De Angelis R, Sant M, Rosso S, Bielska-Lasota M, Coebergh JW, Santaquilani M; EUROCARE Working group. Survival for eight major cancers and all cancers combined for European adults diagnosed in 1995-99: results of the EUROCARE-4 study. Lancet Oncol 2007; 8: 773-83.

\section{Address for correspondence}

Barbara Teresa Madej-Czerwonka MD, PhD

Department of Breast Surgery

Specialist County Hospital of Stephan Cardinal Wyszyński in Lublin Medical University of Lublin, Poland

Al. Kraśnicka 100

20-718 Lublin, Poland

e-mail: basia.madej@interia.pl

Submitted: 26.05.2013

Accepted: $\quad 6.10 .2013$ 